\title{
Prevalence of Workplace Violence and Associated Factors Against Nurses Working in Public Health Facilities in Southern Ethiopia
}

This article was published in the following Dove Press journal: Risk Management and Healthcare Policy

\author{
Haymanot Nigussie \\ Weldehawaryat (iD) \\ Feleke Gebremeskel \\ Weldehawariat $\mathbb{D D}^{2}$ \\ Firdawek Getahun Negash (1D \\ I School of Public Health, Unit of \\ Epidemiology, Arba Minch University, \\ Arba Minch, Ethiopia; ${ }^{2}$ Arba Minch \\ University, School of Public Health, Unit \\ of Reproductive Health, Arba Minch, \\ Ethiopia
}

Background: Workplace violence is an important challenge faced by healthcare providers, especially nurses, throughout the world. But this issue is neglected in developing countries, including Ethiopia. Therefore, the objective of this study was to assess the prevalence of workplace violence and associated factors against nurses working in public health facilities. Methods: A cross-sectional study was conducted in public health facilities in Gamo Gofa zone from February to March 2018. A simple random sampling technique was used to select 354 study respondents from selected public health facilities. The data was collected using a self-administered, pre-tested, and structured questionnaire and analyzed by using SPSS version 21. Descriptive analysis was made and both bi-variable and multivariable logistic regression were applied to identify the factors associated with workplace violence against nurses.

Results: Out of the 348 participants, 150 (43.1\%) nurses had experienced workplace violence. Among these, 47 (13.5\%) had faced physical violence, 98 (28.2\%) had verbal abuse, $36(10.3 \%)$ were bullied/mobbed, and 25 (7.2\%) faced sexual harassment at least once in the last 12 months. Patients' relatives were the leading perpetrators in physical, verbal violence, and bullying, accounting $55.3 \%, 46.9 \%$, and $36.1 \%$, respectively. Female nurses $(\mathrm{AOR}=1.98 ; 95 \% \mathrm{CI}=(1.21,3.25)$, those who live without a spouse $(\mathrm{AOR}=1.98 ; 95 \% \mathrm{CI}=$ $(1.22,3.22)$, those who drink alcohol $(\mathrm{AOR}=1.88 ; 95 \% \mathrm{CI}=(1.03,3.44)$, and those who chew chat $(\mathrm{AOR}=3.24 ; 95 \% \mathrm{CI}=(1.25,8.45)$ were more likely to suffer from workplace violence in public health facilities.

Conclusion: The prevalence of workplace violence against nurses was high. In addition, the characteristics of the occurrences of different types of violence are different beginning from the perpetrators' characteristics to the measures taken by the nurses. In addition, sex, marital status, drinking alcohol, and chewing chat were found statistically significant factors influencing workplace violence against nurses.

Keywords: workplace, violence, public health facilities, Arba Minch, Ethiopia

\section{Introduction}

Workplace Violence (WPV) includes physical assault, homicide, verbal abuse, bullying/mobbing, and sexual harassment that happen at a work site or arising out of the workers' employment. ${ }^{1-4}$ Healthcare providers are among the professionals with a higher risk of WPV. ${ }^{5}$ The rate of occurrence of violence in the healthcare setting is 4-times more often than violence in any other private-sector. ${ }^{3}$ This is because healthcare workers should interact with their patients or clients and their families under difficult circumstances. Patients or clients may act aggressively
Correspondence: Haymanot Nigussie Weldehawaryat

Arba Minch University, School of Public Health, Unit of Epidemiology, Arba Minch, Ethiopia

Email jhaymi463@yahoo.com 
due to their medical condition or medication they are taking. ${ }^{6} \mathrm{WPV}$ is a pandemic manifesting itself in different forms and significantly affecting all professional groups, both gender, and all work settings in the health sector. ${ }^{7}$

As nurses are with direct contact with patients they are at higher risk for violence than other staff in the hospital. ${ }^{3,7}$ Globally different evidence showed that WPV is an important challenge faced by nurses, where greater than $50 \%$ of the nurses faced at least one incident of violence in the last 12 months. $^{8-13}$ Some evidence in Ethiopia also showed that the prevalence of WPV ranges from $29.9-82.8 \%{ }^{14-16}$

The consequences of WPV include minor physical injuries, serious physical injuries, temporary and permanent physical disability, psychological trauma, and death. $^{4,17,18}$ WPV also affects their job motivation and makes them develop a negative attitude to the profession, leaving the healthcare provision at risk. It also leads to immense financial loss in the health sector. ${ }^{18-20}$ Furthermore, the economic burden of workplace violence affects organizations as well as victims, costing billions of dollars in terms of lost wages, medical costs, support costs, lawsuits, etc. ${ }^{8,21,22}$ Moreover, workplace violence has a tremendous psychological and physical impact on the victims, their families, and co-workers. ${ }^{22}$

Besides, as a type of violence, sexual violence has a profound impact on the workplace and society at large. Due to the complex potential effects of sexual violence on physical and mental health, the survivors may need time off from work. Furthermore, when sexual violence occurs in the workplace it can create a climate of fear. And it reduces the productivity, work performance, and wellness of the entire staff. ${ }^{23,24}$

Different evidence has shown that different sociodemographic factors and work-related factors affect WPV against nurses. ${ }^{12-16,18,25,26}$ According to the violence prevention policy, one way to prevent the violence against employees is to have some risk assessment because the risks differ from setting-to-setting. This implies different facilities should develop a comprehensive violence prevention program based on their setting. ${ }^{3,27}$ So, conducting a study to assess the magnitude of the problem and its factors is necessary to take action against workplace violence faced by nurses, who are the front liners in medical care.

Though there are some pieces of evidence showing the prevalence of WPV against nurses, the problem is not well studied in Ethiopia, especially in the southern region. As compared to the impact of the problem, the data available in the area is not sufficient. So, this study will fill the gap in the literature. Therefore, the main aim of this study was to assess the prevalence and also factors associated with WPV against nurses working in Public Health facilities in southern Ethiopia.

\section{Materials and Methods}

\section{Study Setting and Design}

A cross-sectional study was conducted in selected hospitals and health centers of the Gamo Gofa zone, South Nation Nationalities' Peoples Region (SNNPR), from February to March 2018. Gamo Gofa zone is located southwest from Addis Ababa. The total population of the study area is 2,040,972. Three hospitals (one general and two primary hospitals), 76 health centers, and 471 health posts are owned by the government.

\section{Population, Sample Size, and Sampling Study Population}

Nurses who were working in Gamo Gofa zone public health facilities for at least 12 months were included in the study.

\section{Inclusion and Exclusion Criteria}

Nurses who were out for training and other purposes during the data collection period and those nurses who were on maternity leave, sick leave, or annual leave were excluded from the study.

\section{Sample Size Determination}

The sample size was determined by using a single population proportion formula with the assumptions of $95 \%$ confidence interval and margin of error 5\%, prevalence of workplace violence against nurse working in Hawassa public health facilities was $29.9 \%$, and the total sample size with $10 \%$ non-response was 354 nurses. ${ }^{14}$

\section{Sampling Technique and Procedure}

Simple random sampling was used to select 19 public health facilities among 76 public health facilities found in Gamo Gofa Zone. Then the sample size was proportionally allocated to each of the selected public health facilities. And the study participants were selected by simple random sampling by using computer-generated random numbers from the list of the nurses working in each of the selected public health facilities.

\section{Data Collection Techniques}

The questionnaire developed by the International Labour Office (ILO)/International Council of Nurses (ICN)/World 
Health Organization (WHO) and Public Services International (PSI) in 2003 was modified according to the study setting. ${ }^{6}$ The questionnaire was translated into the Amharic language and was back-translated to English before the distribution of the questionnaire to the study participants. To assess the validity of the instrument a pretest was done before the commencement of the data collection using $5 \%$ of the sample size. This was done on a similar population outside of the study area. Final data was collected using a self-administered, Amharic version structured questionnaire. The questionnaire contains sociodemographic, organizational, and perpetrator related questions. The data was collected by ten data collectors who are health professionals and had previous data collection experience. Intensive training was given to data collectors on the objective, relevance of the study, confidentiality of information, respondent's right, about pre-test, and techniques of the interview. The principal and co-investigators conducted on-site supervision during the data collection period and reviewed all filled questionnaires to identify incomplete and incoherent responses.

\section{Data Processing and Analysis}

Each completed questionnaire was checked manually for completeness before data entry. The data was coded and entered into EPI info version 3.5.3 and the data analysis was done by SPSS version 21. Data cleaning was done to check the accuracy and consistency, and any error identified was corrected accordingly. Descriptive analysis was carried out to describe socio-demographic characteristics, the prevalence of different types of violence, the characteristics of perpetrators, and actions taken against violence. Bi-variable and multivariable logistic regression analyses were performed to identify factors associated with workplace violence. Variables having a $P$-value of less than or equal to 0.25 in the bi-variable analysis were entered into the multivariable logistic regression model. ${ }^{28,29}$ Previous findings were also considered to make the variables candidate to the multi-variable model. Adjusted odds ratio with a $95 \%$ confidence interval and the $P$-value was used to assess the strength of association and the statistical significance. The model fitness was checked by Hosmer and Lemeshow goodness of fit test. Finally, the results were presented using tables.

\section{Operational Definitions Workplace Violence}

A person is regarded as suffering from workplace violence when the study participants experienced at least one type of violence such as physical violence, verbal abuse, bullying/mobbing, or sexual harassment in circumstances related to their work in the past 12 months.

\section{Immigration to a Place of Work}

If a person who permanently lives in another area immigrates to live closer to the area of work within the last 5 years.

\section{Drink Alcohol}

Those who take alcohol in public areas or exposed to society more than 2 times a week.

\section{Chewing Chat}

Those who chew chat in public areas or exposed to society more than 2 times a week.

\section{Ethical Considerations}

Ethical clearance was obtained from the Institutional Review Board (IRB) of the College of Medicine and Health Sciences, Arba Minch University. A formal letter of cooperation was obtained from each concerned body and submitted to the respective public health facilities. Informed consent was obtained from each study respondent before the data collection started. The purpose of the research was explained to each study respondent. Participants were also informed that they were able to refuse or withdraw from the study at any time if they were not comfortable. The confidentiality of any information provided by study participants was protected. And the research was conducted following the Ethical Principles for Medical Research Involving Human Subjects mentioned in the Declaration of Helsinki.

\section{Results}

\section{Socio-Demographic Characteristics of Respondents}

Three hundred and forty-eight nurses participated and the response rate was $98.3 \%$. The mean age $( \pm \mathrm{SD})$ of the respondents was $30.7( \pm 7.96)$ years. Out of the total respondents, $197(56.6 \%)$ of them were females and the rest $151(43.4 \%)$ were males. About two-thirds 242, $(69.5 \%)$ of the respondents were below the age of 30 and most of them $218(62.6 \%)$ were married. The majority $(71.3 \%)$ were working in hospitals and the rest were working in the health center (Table 1). 
Table I Socio-Demographic Characteristics of the Nurses Working in Public Health Facilities in Gamogofa Zone, Southern Ethiopia, $2018(n=348)$

\begin{tabular}{|c|c|c|c|c|}
\hline \multirow{2}{*}{ Variables } & \multirow[t]{2}{*}{ Category } & \multicolumn{3}{|c|}{ Workplace Violence } \\
\hline & & Yes, n (\%) & No, n (\%) & Total, n(\%) \\
\hline \multirow[t]{3}{*}{ Age in years } & $18-30$ & $103(68.7)$ & $139(70.2)$ & $242(69.5)$ \\
\hline & $3 I-40$ & $26(17.3)$ & $40(20.2)$ & $66(19.0)$ \\
\hline & $>40$ & $21(14.0)$ & $19(9.6)$ & $40(11.5)$ \\
\hline \multirow[t]{2}{*}{ Sex of participant } & Male & $59(39.3)$ & $92(46.5)$ & I5I (43.4) \\
\hline & Female & $91(60.7)$ & $106(53.5)$ & $197(56.6)$ \\
\hline \multirow[t]{2}{*}{ Marital status } & Live without spouse & $65(43.3)$ & $65(32.8)$ & $130(37.4)$ \\
\hline & Live with spouse & $85(56.7)$ & $133(67.2)$ & $218(62.6)$ \\
\hline \multirow[t]{2}{*}{ Educational level } & Have no Bachelor degree & $102(68.0)$ & $143(72.2)$ & $245(70.4)$ \\
\hline & Bachelor degree & $48(32.0)$ & $55(27.8)$ & $103(29.6)$ \\
\hline \multirow[t]{2}{*}{ Immigration to a place of work } & Yes & $100(66.7)$ & III (56.I) & $211(60.6)$ \\
\hline & No & $50(33.3)$ & $87(43.9)$ & $137(39.4)$ \\
\hline \multirow[t]{3}{*}{ Income in dollars } & $55-147$ & $84(6.0)$ & $123(62.1)$ & $207(59.5)$ \\
\hline & $147.1-239$ & $51(34.0)$ & $67(33.8)$ & 118 (33.9) \\
\hline & $>239$ & $15(10.0)$ & $8(4.0)$ & $23(6.6)$ \\
\hline \multirow[t]{2}{*}{ Alcohol drinking } & Yes & $48(32.0)$ & $29(14.6)$ & $77(22.1)$ \\
\hline & No & $102(68.0)$ & $169(85.4)$ & 271 (77.9) \\
\hline \multirow[t]{2}{*}{ Chewing chat } & Yes & $23(15.3)$ & $8(4.0)$ & $31(8.9)$ \\
\hline & No & 127 (84.7) & $190(96.0)$ & 317 (91.1) \\
\hline \multirow[t]{2}{*}{ Place of work } & Hospital & $105(70.0)$ & 143 (72.2) & 248 (7I.3) \\
\hline & Health center & $45(30.0)$ & $55(27.8)$ & $100(28.7)$ \\
\hline \multirow[t]{2}{*}{ Work experience } & $<10$ years & III (74.0) & $162(81.8)$ & $273(78.4)$ \\
\hline & $\geq 10$ years & $39(26.0)$ & $36(18.2)$ & $75(21.6)$ \\
\hline \multirow[t]{7}{*}{ Working ward } & Pediatrics & $30(20.0)$ & $39(19.7)$ & $69(19.8)$ \\
\hline & Gyn/Obs & $35(23.3)$ & $54(27.3)$ & $89(25.6)$ \\
\hline & Medical & $13(8.7)$ & $22(11.1)$ & $35(10.1)$ \\
\hline & Surgical & $21(14.0)$ & $23(11.6)$ & $44(12.6)$ \\
\hline & OPD & $31(20.7)$ & $45(22.7)$ & $76(21.8)$ \\
\hline & Emergency & $17(11.3)$ & $13(6.6)$ & $30(8.6)$ \\
\hline & Other & $3(2.0)$ & $2(1.0)$ & $5(1.4)$ \\
\hline \multirow[t]{2}{*}{ Working at night } & Yes & $132(88.0)$ & $179(90.4)$ & 311 (89.4) \\
\hline & No & $18(12.0)$ & $19(9.6)$ & $37(10.6)$ \\
\hline \multirow[t]{2}{*}{ Working in shift } & Yes & I34 (89.3) & 176 (88.9) & $310(89.1)$ \\
\hline & No & $16(10.7)$ & $22(11.1)$ & $38(10.9)$ \\
\hline \multirow[t]{3}{*}{ Sex of patient most frequently work with } & Male & $33(22.0)$ & $57(28.8)$ & $90(25.9)$ \\
\hline & Female & $69(46.0)$ & $97(49.0)$ & $166(47.7)$ \\
\hline & Both & $48(32.0)$ & $44(22.2)$ & $92(26.4)$ \\
\hline \multirow[t]{2}{*}{ Sex of immediate supervisor } & Male & $113(75.3)$ & 143 (72.2) & $256(73.6)$ \\
\hline & Female & $37(24.7)$ & $55(27.8)$ & $92(26.4)$ \\
\hline \multirow[t]{2}{*}{ Type of employment } & Full time & 147 (98.0) & $196(99.0)$ & $343(98.6)$ \\
\hline & Part-time & $3(2.0)$ & $2(1.0)$ & $5(1.4)$ \\
\hline
\end{tabular}




\section{Prevalence of Workplace Violence}

Overall, $43.1 \%$ of the respondents reported exposure to workplace violence in the last 12 months. Among the total respondents, 111 (31.9\%) had faced one type and 26 (7.5\%) had faced two types of violence within the last 12 months.

Of the total respondents, 47 (13.5\%) had faced physical violence in the past 12 months. Most (85.5\%) of the physical violence happened without using any weapon and, among the physical violence experienced by the nurses, $26(55.3 \%)$ instances were committed by patients' relatives, and most $44(93.6 \%)$ of the perpetrators of physical violence were males (Table 2).

Among the total respondents, 98 (28.2\%) reported exposure to verbal abuse in the past 12 months. Most 46 (46.9\%) of the perpetrators of verbal abuse were relatives of the patients/ clients, followed by staff members 18 (18.4\%) (Table 3).

Concerning bullying/mobbing, $36(10.3 \%)$ of the respondents experienced bullying/mobbing in the past 12 months. And 13 (36.1\%) of the perpetrators of the bullying/mobbing were relatives of the patients and $26(72.2 \%)$ were males. Besides, $97.2 \%$ of the bullying occurred inside the health institution and $24(66.7 \%)$ instances took place during daytime (Table 3 ).

Of the respondents, 25 (7.2\%) had at least one incident of sexual harassment in the past 12 months. Of these, 10 (40\%) were committed by other staff members and $76 \%$ were committed by male persons. Out of the total sexual harassment committed against the nurses, 20 (80\%) happened during daytime and the same amount took place inside the health institution (Table 3).

\section{Actions Taken Against Workplace Violence Among Nurses}

Among those nurses who were victims of physical violence, $20(42.6 \%)$ took action, but $57.4 \%$ did not take any measure against the physical violence they faced. Among the nurses who took at least one action for physical violence, $11(50 \%)$ of them prosecuted their perpetrators. More than half (53.1\%) of the nurses took action against the verbal abuse that happened against them. The most common measure taken for the verbal abuse was telling a friend or colleague $16(30 \%)$. Among nurses who faced bullying/mobbing and sexual harassment in the previous 12 months, $22(61.1 \%)$ and $16(64 \%)$ took at least one measure, respectively. The commonest measure for the bullying/mobbing and sexual harassment was telling the perpetrator to stop. Besides, 264 (75\%) showed an unavailability of reporting procedures in their institution.
Table 2 Physical Violence Against Nurses Working in Public Health Facilities in Gamogofa Zone, Southern Ethiopia, 2018

\begin{tabular}{|c|c|c|c|}
\hline Variables & Category & Frequency & $\begin{array}{l}\text { Percent } \\
\text { (\%) }\end{array}$ \\
\hline Physical violence & $\begin{array}{l}\text { Yes } \\
\text { No }\end{array}$ & $\begin{array}{l}47 \\
301\end{array}$ & $\begin{array}{l}13.5 \\
86.5\end{array}$ \\
\hline Incident type & $\begin{array}{l}\text { With } \\
\text { a weapon } \\
\text { Without } \\
\text { weapon }\end{array}$ & $\begin{array}{l}7 \\
40\end{array}$ & $\begin{array}{l}14.9 \\
85.5\end{array}$ \\
\hline $\begin{array}{l}\text { Consider as typical } \\
\text { violence }\end{array}$ & $\begin{array}{l}\text { Yes } \\
\text { No }\end{array}$ & $\begin{array}{l}29 \\
18\end{array}$ & $\begin{array}{l}61.7 \\
38.3\end{array}$ \\
\hline Physical perpetrator & $\begin{array}{l}\text { Patient/client } \\
\text { Staff member } \\
\text { External } \\
\text { colleague/ } \\
\text { worker } \\
\text { Relatives of } \\
\text { patient/client } \\
\text { Supervisor }\end{array}$ & $\begin{array}{l}12 \\
2 \\
2 \\
26 \\
4\end{array}$ & $\begin{array}{l}25.5 \\
4.3 \\
4.3 \\
\\
55.3 \\
8.5\end{array}$ \\
\hline Sex of perpetrator & $\begin{array}{l}\text { Male } \\
\text { Female }\end{array}$ & $\begin{array}{l}44 \\
3\end{array}$ & $\begin{array}{l}93.6 \\
6.4\end{array}$ \\
\hline Perpetrator in anxiety & $\begin{array}{l}\text { Yes } \\
\text { No } \\
\text { I do not know }\end{array}$ & $\begin{array}{l}9 \\
30 \\
8\end{array}$ & $\begin{array}{l}19.1 \\
63.8 \\
17.0\end{array}$ \\
\hline $\begin{array}{l}\text { Perpetrator mental } \\
\text { illness }\end{array}$ & $\begin{array}{l}\text { Yes } \\
\text { No } \\
\text { I do not know }\end{array}$ & $\begin{array}{l}1 \\
40 \\
6\end{array}$ & $\begin{array}{l}85.1 \\
12.8\end{array}$ \\
\hline $\begin{array}{l}\text { Place of physical } \\
\text { violence }\end{array}$ & $\begin{array}{l}\text { Inside health } \\
\text { institution } \\
\text { Outside health } \\
\text { institution }\end{array}$ & $\begin{array}{l}41 \\
6\end{array}$ & $\begin{array}{l}87.2 \\
12.8\end{array}$ \\
\hline $\begin{array}{l}\text { Time of physical } \\
\text { violence }\end{array}$ & $\begin{array}{l}\text { Evening } \\
\text { Day }\end{array}$ & $\begin{array}{l}19 \\
28\end{array}$ & $\begin{array}{l}40.4 \\
59.6\end{array}$ \\
\hline Physically injured & $\begin{array}{l}\text { No } \\
\text { Yes }\end{array}$ & $\begin{array}{l}40 \\
7\end{array}$ & $\begin{array}{l}85.1 \\
14.9\end{array}$ \\
\hline $\begin{array}{l}\text { Seek treatment for } \\
\text { physical injury }(n=7)\end{array}$ & $\begin{array}{l}\text { No } \\
\text { Yes }\end{array}$ & $\begin{array}{l}2 \\
5\end{array}$ & 71.4 \\
\hline $\begin{array}{l}\text { Took an action for } \\
\text { physical violence }\end{array}$ & $\begin{array}{l}\text { Yes } \\
\text { No }\end{array}$ & $\begin{array}{l}22 \\
25\end{array}$ & $\begin{array}{l}46.8 \\
53.2\end{array}$ \\
\hline
\end{tabular}

\section{Factors Associated with Workplace Violence Against Nurses}

The sex of the respondent, marital status, immigration to a place of work, work experience, drinking alcohol, chewing chat, and sex of patient were included in the multivariable logistic regression analysis. And in the multivariable 
Table 3 Verbal Abuse, Bullying/Mobbing, and Sexual Harassment Against Nurses Working in Public Health Facilities in Southern Ethiopia, 2018

\begin{tabular}{|c|c|c|c|c|c|c|c|}
\hline \multirow[t]{2}{*}{ Variables } & \multirow[t]{2}{*}{ Category } & \multicolumn{2}{|c|}{ Verbal Abuse } & \multicolumn{2}{|c|}{ Bullying/Mobbing } & \multicolumn{2}{|c|}{ Sexual Harassment } \\
\hline & & Frequency & $\begin{array}{l}\text { Percent } \\
\text { (\%) }\end{array}$ & Frequency & $\begin{array}{l}\text { Percent } \\
(\%)\end{array}$ & Frequency & $\begin{array}{l}\text { Percent } \\
(\%)\end{array}$ \\
\hline Violence in the past 12 months & Yes & 98 & 28.2 & 36 & 10.3 & 25 & 7.2 \\
\hline$(n=348)$ & No & 250 & 71.8 & 312 & 89.7 & 323 & 92.8 \\
\hline \multirow[t]{2}{*}{ How often abused } & Sometimes & 62 & 63.3 & 22 & 61.1 & 8 & 32 \\
\hline & Once & 36 & 36.7 & 14 & 38.9 & 17 & 68 \\
\hline \multirow[t]{7}{*}{ Perpetrator of the violence } & Patient/client & 12 & 12.2 & 4 & $\mathrm{II} . \mathrm{I}$ & $\mathrm{I}$ & \\
\hline & Staff member & 18 & 18.4 & 7 & 19.4 & 10 & 40.0 \\
\hline & External colleague/ & 4 & 4.1 & 2 & 5.6 & 0 & \\
\hline & worker & 46 & 469 & 13 & 361 & 1 & \\
\hline & $\begin{array}{l}\text { Relatives of patient/ } \\
\text { client }\end{array}$ & 46 & 46.9 & 13 & 36.1 & 1 & \\
\hline & Supervisor & 15 & 15.3 & 5 & 13.9 & 8 & 32.0 \\
\hline & General public & 3 & 3.0 & 5 & 13.9 & 5 & 20.0 \\
\hline \multirow[t]{2}{*}{ Perpetrator's sex } & Male & 79 & 80.6 & 26 & 72.2 & 19 & 76.0 \\
\hline & Female & 19 & 19.4 & 10 & 27.8 & 6 & 24.0 \\
\hline \multirow[t]{3}{*}{ Perpetrator in anxiety? } & Yes & 28 & 28.6 & 5 & 13.9 & 0 & \\
\hline & No & 53 & 54.1 & 22 & 61.1 & 23 & 92.0 \\
\hline & I do not know & 17 & 17.3 & 9 & 25.0 & 2 & \\
\hline \multirow[t]{3}{*}{ Was perpetrator mentally ill } & Yes & 3 & 3.1 & 2 & 5.6 & 0 & \\
\hline & No & 82 & 83.7 & 27 & 75.0 & 24 & 96.0 \\
\hline & I do not know & 13 & 13.3 & 7 & 19.4 & 1 & \\
\hline \multirow[t]{2}{*}{ Consider as typical violence } & No & 29 & 29.6 & 13 & 36.1 & 3 & 12.0 \\
\hline & Yes & 69 & 70.4 & 23 & 63.9 & 22 & 88.0 \\
\hline \multirow[t]{2}{*}{ Place of violence } & $\begin{array}{l}\text { Inside health } \\
\text { institution }\end{array}$ & 92 & & 35 & 97.2 & 20 & 80 \\
\hline & $\begin{array}{l}\text { Outside health } \\
\text { institution }\end{array}$ & 6 & 6.1 & 1 & & 5 & 20 \\
\hline \multirow[t]{2}{*}{ Time of verbal abuse } & Evening & 28 & 28.6 & 12 & 33.3 & 5 & 20 \\
\hline & Day time & 70 & 71.4 & 24 & 66.7 & 20 & 80 \\
\hline
\end{tabular}

analysis, the sex of the respondent, marital status, drinking alcohol, and chewing chat were found to be statistically significant factors. Female nurses were 2-times more likely to have workplace violence $(\mathrm{AOR}=1.98 ; 95 \% \mathrm{CI}=1.21,3.25)$ than male nurses. Those who live without a spouse were also 2-times more likely to face workplace violence than those who lived with their spouse $(\mathrm{AOR}=1.98 ; 95 \% \mathrm{CI}=1.22$, 3.22). Those who drink alcohol had higher odds of facing workplace violence than those who did not drink alcohol $(\mathrm{AOR}=1.88 ; 95 \% \mathrm{CI}=1.03,3.44)$. Besides, those who chew chat were 3 -times more likely to face workplace violence than those nurses who do not chew chat $(\mathrm{AOR}=3.24 ; 95 \%$ $\mathrm{CI}=1.25,8.45$ ) (Table 4).

\section{Discussion}

This study revealed $43.1 \%(95 \% \mathrm{CI}=37.9-48.6)$ of nurses encounter WPV. This finding is consistent with studies conducted in Saudi Arabia (45.6\%) and Rwanda (39\%). ${ }^{18,19}$ But which is lower as compared to the studies conducted in United States (76\%), Northeastern China (83.3\%), China (65\%), Jordan (55.5\%), Palestine (80.4\%), Korea (95.5\%), Indonesia (54.6\%), Gambia (62.1\%), and Oromia, Ethiopia (82.8\%). ${ }^{8-13,16,18,30}$ This might be due to socio-cultural differences and differences in healthcare systems. And it might also be due to under-reporting of the violent events. The magnitude of WPV was higher when compared to the study conducted in Ethiopia, Amhara 
Table 4 Factors Associated with Workplace Violence Against Nurses Working in Public Health Facilities in Gamo Gofa Zone, Southern Ethiopia, 2018

\begin{tabular}{|c|c|c|c|c|c|c|c|}
\hline \multirow[t]{2}{*}{ Variables } & \multirow[t]{2}{*}{ Category } & \multicolumn{2}{|c|}{$\begin{array}{l}\text { Workplace } \\
\text { Violence }\end{array}$} & \multirow[t]{2}{*}{ COR $(95 \% \mathrm{Cl})$} & \multirow[t]{2}{*}{$P$-value } & \multirow[t]{2}{*}{ AOR $(95 \% \mathrm{Cl})$} & \multirow[t]{2}{*}{$P$-value } \\
\hline & & Yes & No & & & & \\
\hline Sex of respondent & $\begin{array}{l}\text { Male } \\
\text { Female }\end{array}$ & $\begin{array}{l}59 \\
91\end{array}$ & $\begin{array}{l}92 \\
106\end{array}$ & I.34 $(0.87,2.06)$ & 0.184 & $\begin{array}{l}\text { I } \\
1.98(1.21,3.25)^{* *}\end{array}$ & 0.007 \\
\hline Marital status & $\begin{array}{l}\text { Living without spouse } \\
\text { Living with a spouse }\end{array}$ & $\begin{array}{l}65 \\
85\end{array}$ & $\begin{array}{l}65 \\
133\end{array}$ & $\begin{array}{l}1.56(\mathrm{I} .0 \mathrm{I}, 2.42) \\
\mathrm{I}\end{array}$ & 0.045 & $\begin{array}{l}1.98(1.22,3.22)^{* *} \\
\text { I }\end{array}$ & 0.006 \\
\hline Immigration to a place of work & $\begin{array}{l}\text { Yes } \\
\text { No }\end{array}$ & $\begin{array}{l}100 \\
50\end{array}$ & $\begin{array}{l}111 \\
87\end{array}$ & $\begin{array}{l}\mathrm{I} .568(1.0 \mathrm{I}, 2.43) \\
\mathrm{I}\end{array}$ & 0.045 & $\begin{array}{l}\text { I.47 (0.9I, 2.37) } \\
\text { I }\end{array}$ & 0.118 \\
\hline Work experience & $\begin{array}{l}<10 \text { years } \\
\geq 10 \text { years }\end{array}$ & $\begin{array}{l}111 \\
39\end{array}$ & $\begin{array}{l}162 \\
36\end{array}$ & $\begin{array}{l}0.63(0.38,1.06) \\
1\end{array}$ & 0.080 & $\begin{array}{l}0.67(0.36,1.22) \\
1\end{array}$ & 0.191 \\
\hline Drinking alcohol & $\begin{array}{l}\text { Yes } \\
\text { No }\end{array}$ & $\begin{array}{l}48 \\
102\end{array}$ & $\begin{array}{l}29 \\
169\end{array}$ & $\begin{array}{l}2.742(1.62,4.62) \\
\mathrm{I}\end{array}$ & 0.0001 & $\begin{array}{l}\mathrm{I} .88(1.03,3.44)^{* *} \\
\mathrm{I}\end{array}$ & 0.04 \\
\hline Chewing chat & $\begin{array}{l}\text { Yes } \\
\text { No }\end{array}$ & $\begin{array}{l}23 \\
127\end{array}$ & $\begin{array}{l}8 \\
190\end{array}$ & $\begin{array}{l}4.30(1.87,9.92) \\
1\end{array}$ & 0.001 & $\begin{array}{l}3.24(1.25,8.45)^{* *} \\
\text { । }\end{array}$ & 0.016 \\
\hline $\begin{array}{l}\text { Sex of patient most frequently work } \\
\text { with }\end{array}$ & $\begin{array}{l}\text { Male } \\
\text { Female } \\
\text { Both }\end{array}$ & $\begin{array}{l}33 \\
69 \\
48\end{array}$ & $\begin{array}{l}57 \\
97 \\
44\end{array}$ & $\begin{array}{l}0.531(0.29,0.96) \\
0.652(0.39, I .089) \\
\text { I }\end{array}$ & $\begin{array}{l}0.036 \\
0.102\end{array}$ & $\begin{array}{l}0.6 \mathrm{I}(0.32, \mathrm{I} .18) \\
0.76(0.43,1.35) \\
\mathrm{I}\end{array}$ & $\begin{array}{l}0.143 \\
0.350\end{array}$ \\
\hline
\end{tabular}

Note: **Shows $P<0.05$.

region (26.7\%). ${ }^{15}$ This might be due to the difference in setting that the research in the Amhara region was conducted only in referral hospitals. This may also be due to the time differences that the people in recent times may enter to different socio-economic instabilities which may be taken as a pushing factor for violence that happened against nurses. The prevalence in this study is also higher compared to the study conducted in Hawassa public health facilities $(29.9 \%) .{ }^{14}$ This might be due to the definition deference as the study in Hawassa used the last 6 months before the data collection to define workplace violence but this study used the last 12 months prior to the data collection to define workplace violence. Among different kinds of violence at the workplace, verbal abuse was found to be the commonest one in this study, which is consistent with different studies conducted in different countries. ${ }^{12,16,18,31,32}$ This might be because verbal abuse is easy for perpetrators to commit and most of the time this type of violence will not leave the victim with tangible evidence to take action against.

In this study, similar to many of the previous studies the patient relatives' and patients were frequently reported as the main source of violence. ${ }^{16,18,33,34}$ This might be because the patients and patient relatives have contact with the nurses in stressful situations.
Furthermore, nurses have close and longer contact with the patients and their relatives.

The sex of the nurses had a significant association with workplace violence; females had higher odds of being exposed to workplace violence than males. This is in line with studies conducted in Jordan, Palestine, and Hawassa. This might be due to the negative community attitude towards female power and ability. ${ }^{14,18,30}$

Marital status was also found to have a statistically significant association with WPV against nurses. This finding was consistent with a study conducted in northwest Ethiopia. ${ }^{15}$ This study showed that those nurses who lived without a spouse were 2-times more likely to be exposed to WPV than those who lived with their spouse. This might be because most of the nurses who live without a spouse are young person's less than 30 years old, which can be taken as a predictor for WPV in different studies. ${ }^{11,14,16,32,34}$

Those nurses who drink alcohol and chew chat are also more likely to have WPV than those persons who do not. This might happen because such kinds of substances may lead them to do their task haphazardly so that different persons might try to commit violence on them. Or this might be because in most small cities the personal life of 
the nurses is not hidden and culturally persons who drink alcohol and chew chat are given less value by the perpetrators.

The limitation of this study might be recall bias because the retrospective approach needs the nurses to remember the workplace violence in the last 12 months. Furthermore, the study does not include perpetrator factors as the perpetrators cannot be tracked at the time of the study.

\section{Conclusions}

In this study, the prevalence of workplace violence in the last 12 months in the Gamo Gofa zone public health facilities was $43.1 \%$. The findings also revealed that the characteristics of the occurrences of different types of violence are different beginning from the perpetrators' characteristics to the measures taken by the nurses. In addition, sex, marital status, drinking alcohol, and chewing chat were found to be statistically significant factors that influence workplace violence against nurses.

As female nurses are more likely to experience violence it is recommended that policymakers and other stakeholders give special attention to them. Furthermore, there is no reporting procedure for the violent events that happened against the nurses so it is important to arrange an organized system of reporting violence. Furthermore, it is better to help in the way the nurses can take action for violence committed against them.

\section{Abbreviations}

ILO, International Labour Office; ICN, International Council of Nurses; IRB, Institutional Review Board; OPD, Outpatient Departments; PSI, Public Services International; SNNPR, South Nation Nationalities' Peoples Region; SPSS, software package for social science; WHO, World Health Organization.

\section{Data Sharing Statement}

The datasets used and/or analyzed during the current study are available from the corresponding author on reasonable request.

\section{Acknowledgments}

We would like to give our gratitude to the nurses who gave us their valuable information. We would also like to forward our heartfelt thanks to the Gamo Gofa zone health office and health institutions for their cooperation and Arba Minch University for its financial support. We would also like to acknowledge the data collectors for their effort.

\section{Author Contributions}

All authors made a significant contribution on the conception of the study, in the data collection, data analysis, and interpretation. All authors took part in drafting, revising, or critically reviewing the article, gave final approval of the version to be published, have agreed on the journal to which the article has been submitted; and agree to be accountable for all aspects of the work.

\section{Funding}

The fund for the data collection was obtained from Arba Minch University.

\section{Disclosure}

The authors declare that they have no competing interests for this work.

\section{References}

1. Waddington PA, Badger D, Bull R. Appraising the inclusive definition of workplace 'violence'1. Br J Criminol. 2005;45(2):141-164. doi:10.1093/bjc/azh052

2. Workers' Compensation Board of British Columbia. Preventing Violence in Health Care: Five Steps to an Effective Program. Richmond: Workers' Compensation Board of British Columbia; 2000.

3. NIOSH. Violence occupational hazards in hospitals. DHHS (NIOSH) Publication Number 2002-101.April, 2002.

4. Occupational Safety and Health Administration. Guidelines for Preventing Workplace Violence for Healthcare and Social Service Workers (OSHA Publication 3148-06R). Washington: Department of Labor; 2016.

5. Center for Personal Protection \& Safety. Managing the threats of workplace violence. 2017.

6. ICN I. WHO. Workplace violence in the health sector country case studies research instruments. ILO/ICN/WHO/PSI. 2003.

7. Di Martino V. Workplace Violence in the Health Sector. Country Case Studies Brazil, Bulgaria, Lebanon, Portugal, South Africa, Thailand and an Additional Australian Study. Ginebra: Organización Internacional del Trabajo; 2002:3-42.

8. Speroni KG, Fitch T, Dawson E, Dugan L, Atherton M. Incidence and cost of nurse workplace violence perpetrated by hospital patients or patient visitors. J Emerg Nurs. 2014;40(3):218-228. doi:10.1016/j. jen.2013.05.014

9. Choi SH, Lee H. Workplace violence against nurses in Korea and its impact on professional quality of life and turnover intention. $J$ Nurs Manag. 2017;25(7):508-518. doi:10.1111/jonm.12488

10. Noorana Zahra A, Feng JY. Workplace violence against nurses in Indonesian emergency departments. Enferm Clin. 2018;28(Suppl 1):184-190. doi:10.1016/S1130-8621(18)30064-0

11. Sun P, Zhang X, Sun Y, et al. Workplace violence against health care workers in North Chinese hospitals: a cross-sectional survey. Int J Environ Res Public Health. 2017;14(1):96. doi:10.3390/ ijerph14010096

12. Shi L, Zhang D, Zhou C, et al. A cross-sectional study on the prevalence and associated risk factors for workplace violence against Chinese nurses. BMJ Open. 2017;7(6):e013105. doi:10.1136/bmjopen-2016-013105 
13. Sisawo EJ, Ouédraogo SY, Huang SL. Workplace violence against nurses in the Gambia: mixed methods design. BMC Health Serv Res. 2017;17(1):311. doi:10.1186/s12913-017-2258-4

14. Fute M, Mengesha ZB, Wakgari N, Tessema GA. High prevalence of workplace violence among nurses working at public health facilities in Southern Ethiopia. BMC Nurs. 2015;14(1):9. doi:10.1186/s12912015-0062-1

15. Tiruneh BT, Bifftu BB, Tumebo AA, Kelkay MM, Anlay DZ, Dachew BA. Prevalence of workplace violence in Northwest Ethiopia: a multivariate analysis. BMC Nurs. 2016;15(1):1-6. doi:10.1186/s12912-016-0162-6

16. Likassa T, Gudissa T, H Mariam W, Jira C. Assessment of factors associated with workplace violence against nurses among referral hospitals of Oromia Regional State, Ethiopia. J Health Med Nurs. 2017;35.

17. World Health Organization. World Report on Violence and Health: Summary. Geneva: WHO; 2002. Available from:: http://www.who. int/violence_injury_prevention/violence/world_report/en/summary_ en.pdf. Accessed September 5, 2020.

18. Kitaneh M, Hamdan M. Workplace violence against physicians and nurses in Palestinian public hospitals: a cross-sectional study. BMC Health Serv Res. 2012;12(1):1-9. doi:10.1186/1472-6963-12-469

19. Needham I, Kingma M, McKenna K, Frank O. Proceedings of the Fourth International Conference on Violence in the Health Sector Towards Safety, Security and Wellbeing for All. KAVANAH. USA; October, 2014.

20. Najafi F, Fallahi-Khoshknab M, Ahmadi F, Dalvandi A, Rahgozar M. Antecedents and consequences of workplace violence against nurses: a qualitative study. J Clin Nurs. 2018;27(1-2):e116-e128. doi:10. 1111/jocn.13884

21. Schmidtke R. Workplace violence: identification and prevention. J Global Health Care Systems. 2011;1:2.

22. Friend MA, Kohn JP. Fundamentals of Occupational Safety and Health. Rowman \& Littlefield; 2018:16.

23. Sexual Violence Resource Center. Sexual Violence\& the Workplace: A Guide for Employers National Centers for Disease Control and Prevention; 2013.
24. McDonald P. Workplace sexual harassment 30 years on: a review of the literature. Int J Manage Rev. 2012;14(1):1-17.

25. Turki N, Afify AA, AlAteeq M. Violence against health workers in family medicine centers. J Multidiscip Healthc. 2016;9:257-266.

26. Shafran-Tikva S, Zelker R, Stern Z, Chinitz D. Workplace violence in a tertiary care Israeli hospital - a systematic analysis of the types of violence, the perpetrators and hospital departments. Isr $J$ Health Policy Res. 2017;6(1):43. doi:10.1186/s13584-017-0168-x

27. Victoria W. A Guide for Employers, Preventing and Responding to Work Related Violence. Victoria, Australia: WorkSafe Victoria; 2015.

28. Maldonado G, Greenland S. Simulation study of confounder-selection strategies. Am J Epidemiol. 1993;138(11):923-936. doi:10.1093/oxfordjournals.aje.a116813

29. Bursac Z, Gauss CH, Williams DK, Hosmer DW. Purposeful selection of variables in logistic regression. Source Code Biol Med. 2008;3 (1):17. doi:10.1186/1751-0473-3-17

30. Ahmed AS. 318 verbal and physical abuse against Jordanian nurses in the work environment. East Mediterr Health J. 2012;18 (4):318-324. doi: $10.26719 / 2012.18 .4 .318$

31. IntraHealth International/Capacity Project. Workplace Violence and Gender Discrimination in the Health Sector in Rwanda. September, 2009.

32. Kamchuchat C, Chongsuvivatwong V, Oncheunjit S, Yip TW, Sangthong R. Workplace violence directed at nursing staff at a general hospital in southern Thailand. J Occup Health. 2008;50 (2):201-207. doi:10.1539/joh.O7001

33. Gerberich SG, Church TR, McGovern PM, et al. An epidemiological study of the magnitude and consequences of work related violence: the Minnesota Nurses' Study. Occup Environ Med. 2004;61 (6):495-503. doi:10.1136/oem.2003.007294

34. Abou-ElWafa HS, El-Gilany AH, Abd-El-Raouf SE, Abd-Elmouty SM, El-Sayed Hassan E-SR. Workplace violence against emergency versus non-emergency nurses in Mansoura university hospitals, Egypt. J Interpers Violence. 2015;30(5):857-872. doi:10.1177/ 0886260514536278
Risk Management and Healthcare Policy

\section{Publish your work in this journal}

Risk Management and Healthcare Policy is an international, peerreviewed, open access journal focusing on all aspects of public health, policy, and preventative measures to promote good health and improve morbidity and mortality in the population. The journal welcomes submitted papers covering original research, basic science, clinical \& epidemiological studies, reviews and evaluations, guidelines, expert opinion and commentary, case reports and extended reports. The manuscript management system is completely online and includes a very quick and fair peer-review system, which is all easy to use. Visit http://www.dovepress.com/testimonials.php to read real quotes from published authors. 